\title{
Komentarz do artykułu Hikmat H. Madzitow i wsp. Assessment of the efficacy of primary percutaneous coronary intervention in patients with ST-segment elevation myocardial infarction based on the ECG analysis
}

\author{
Robert J. Gil ${ }^{1,2}$ \\ ${ }^{1}$ Klinika Kardiologii Inwazyjnej CSK MSWiA, Warszawa, Polska \\ 2Instytut Medycyny Doświadczalnej i Klinicznej PAN, Warszawa, Polska
}

Post Kardiol Interw 2011; 7, 4 (26): 297-298 DOI: $10.5114 /$ pwki.2011.25788

Nie wątpię, że dla znacznej części Czytelników Postępów w Kardiologii Interwencyjnej już sam fakt powstania powyższego artykułu w Uzbekistanie jest sporym zaskoczeniem. Komentarz do niego będzie raczej nietypowy. Praca została napisana profesjonalnie i choć nie należy do tzw. przełomowych, to okazuje się ciekawa, chociażby ze względu na próbę oceny wyników leczenia ostrych zespotów wieńcowych (OZW) nie tylko na podstawie obrazu angiograficznego. Nie tylko ja odnoszę wrażenie, że sukces interwencyjnego leczenia OZW w Polsce przysłonił nam trochę te inne metody. Nie od dziś wiadomo, że ludzi chcących działać naukowo jest wielu, nie tylko w wysoko rozwiniętych krajach zachodnich. Cieszę się bardzo, że Redakcja Postępów w Kardiologii Interwencyjnej, udostępniając łamy czasopisma, dała taką szansę walczącym o swój rozwój naukowy Kolegom z Uzbekistanu.

Co wiemy o Uzbekistanie, oprócz okresowych doniesień prasowych czy telewizyjnych, skupiających się przede wszystkim na aspektach politycznych? Otóż jest to kraj leżący w Azji Środkowej, na przebiegu tzw. Jedwabnego Szlaku i już chociażby z tego powodu mający przebogatą historię. Skądinąd wiem, że prawie każdy słyszał o takich miastach, jak Samarkanda czy Buchara, tyle że nie każdy kojarzy je z Uzbekistanem! Ponadto znany jest nam Awicenna (Ibn Sina, Abu 'Ali al-Husayn Ibn Sina), o którym młodzi medycy dowiadują się na zajęciach z historii medycyny. Okazuje się, że był on mieszkańcem Buchary! Ze względu na swoje dokonania naukowe (m.in. dotyczące wrzodów żołądka, nastawiania złamanych kończyn, różnicowania między zapaleniem opon mózgowych a chorobami mózgu) słusznie nazywany jest ojcem medycyny i stomatologii (pierwszy zalecał mycie zębów). Wiele mówi o nim jego motto życiowe: „Ten, co wie, że wie - jego słuchajcie. Ten, co wie, że nie wie - jego pouczcie. Ten, co nie wie, że wie - jego obudźcie. Ten, co nie wie, że nie wie zostawcie go samemu sobie".

Okres świetności terenów obecnego Uzbekistanu to przede wszystkim XIV i XV wiek. W tym kontekście nie można nie wspomnieć Timura Wielkiego. Warto również uświadomić sobie, że w XIX wieku tereny te były obiektem rywalizacji carskiej Rosji oraz Imperium Brytyjskiego! Kończąc ten krótki rys historyczny, pozwolę sobie jeszcze dodać, że w 1924 roku powstała Uzbecka Socjalistyczna Republika Radziecka, a po rozpadzie ZSRR 31 sierpnia 1991 roku została ogłoszona deklaracja niepodległości tego kraju.

Uzbekistan powierzchniowo zajmuje 57. miejsce na świecie, ale przy gęstości zaludnienia 62 osoby na 1 km² plasuje się na 42. miejscu pod względem liczby mieszkańców. Uzbekistan to kraj rolniczy, w którym największe znaczenie gospodarcze od lat ma uprawa bawełny, produkcja jedwabiu, hodowla owiec oraz sadownictwo. Znawcy tematu jednoznacznie twierdzą, że owoce i warzywa z Uzbekistanu od wielu lat królują np. w Rosji. Kraj ten nie jest pozbawiony cennych surowców mineralnych. Pewnie zaskoczy to wielu, ale pod względem zasobów złota zajmuje on 4. miejsce na świecie, a prace badawcze dotyczące ropy naftowej i gazu ziemnego napawają dużą nadzieją.

Uzbekistan, a właściwie Republika Uzbekistanu, pod względem administracyjnym dzieli się na 12 regionów (wilajetów) i jedną republikę autonomiczną (Karakałpacja), a jej stolicą jest Taszkent. Miasto to liczy ponad $2 \mathrm{mln}$ mieszkańców (szacunki oficjalne z 2008 roku - 2,18 mln, natomiast nieoficjalne dodają milion). Warto wspomnieć, że 
Taszkent jest jednym z największych miast Azji Środkowej, a swoją bardzo ciekawą, przemyślaną organizację i architekturę zawdzięcza gruntownej przebudowie po trzęsieniu ziemi 26 kwietnia 1966 roku.

Przepraszam za to odbiegnięcie od właściwego tematu, tj. komentarza pracy naukowej, jednak uznałem, że warto przy okazji publikacji pierwszej - według mojej wiedzy - w polskim czasopiśmie medycznym pracy z Uzbekistanu dotyczącej kardiologii (a kto wie, czy nawet nie medycyny) poszerzyć swoje horyzonty i przypomnieć sobie, że my również jeszcze niedawno byliśmy daleko od obecnych standardów.

W sierpniu bieżącego roku spędziłem w Taszkencie 5 dni, biorąc udział w szkoleniu lekarzy uzbeckich zajmujących się kardiologią interwencyjną. Pierwszy kontakt z mieszkańcami tego miasta wręcz mnie zaskoczył. Okazuje się, że wielu ludzi spotkanych przeze mnie pamięta armię Andersa, której oddziały zostały w 1942 roku przeniesione w okolice Taszkentu. Co więcej, zachowali o niej bardzo dobre wspomnienia! Druga sprawa to stale podkreślany fakt przynależności Polski do Unii Europejskiej, co kojarzone jest jednoznacznie z wysokim poziomem życia i dobrobytem. Z kolei lekarze zajmujący się kardiologią byli doskonale poinformowani o naszych osiągnięciach w zakresie inwazyjnego leczenia OzW.

W Taszkencie znajduje się 5 ośrodków kardiologii, natomiast 4 z nich mają kardioangiografy i wykonuje się tam koronarografie oraz angioplastyki wieńcowe. Według informacji uzyskanych z tamtejszego Ministerstwa Zdrowia w najbliższych latach ośrodki kardiologii interwencyjnej powstaną jeszcze w kilku stolicach regionów. Na razie poza Taszkentem istnieje tylko jeden - w Namaganie, gdzie wykonuje się jedynie koronarografie diagnostyczne. Od ponad 2 lat w ośrodku autorów komentowanej pracy realizowany jest program 24-godzinnego dyżuru dla chorych z OZW. W 2010 roku w Taszkencie wykonano w sumie około 2750 angioplastyk wieńcowych, w tym około 350 u chorych z OZW (przede wszystkim STEMI). Bieżący rok wydaje się wręcz przełomowy. Tylko w ośrodku autorów, tj. w Centrum Federalnym, metodami kardiologii interwencyjnej leczonych będzie blisko 2000 chorych.

Te kilka dni pracy w Taszkencie zrobiło na mnie duże wrażenie. Złożyło się na to ogromne zaangażowanie lekarzy, którzy nie patrzą na zegarek (jednego dnia skończyliśmy zabiegi około północy) i stale zadają konkretne pytania dotyczące kwalifikacji czy techniki wykonywania poszczególnych zabiegów przezskórnej angioplastyki. Jednym zdaniem, pasja znana nam z lat 90. XX wieku! Nie ukrywam, że pozytywnie zaskoczyły mnie wysokie umiejętności tamtejszych specjalistów. Jest ich niestety tylko kilku, ale widać, że wcześniejsze szkolenia, organizowane głównie w Rosji, były efektywne.

Oczywiście, jak wszędzie, tak i w Taszkencie widziałem tzw. obiektywne problemy. Do największych należy brak powszechnego systemu ubezpieczeń zdrowotnych. Według mnie właśnie ten fakt znacznie utrudnia rozwój tamtejszej kardiologii interwencyjnej (i zapewne całej medycyny). W ostatnich latach państwo sukcesywnie zwiększało kwoty przeznaczone na wysoko specjalistyczne procedury kardiologii interwencyjnej, ale to wciąż kropla w morzu potrzeb. W konsekwencji bardzo wiele zależy od zamożności rodzin i ich determinacji. Spore problemy dotyczą również sprowadzenia jednorazowego sprzętu specjalistycznego. Dzieje się tak ze względu na dość restrykcyjne wymogi techniczne i administracyjne oraz długi czas niezbędny do uzyskania tzw. rejestracji produktu. W efekcie nie wszystkie firmy sprzętowe działają czynnie w Uzbekistanie, chociaż w trakcie mojego pobytu widziałem stenty wielu znanych na rynku producentów. Remedium na te wszystkie problemy jest oczywiście i nam dobrze znana z przeszłości (czy ktoś to jeszcze pamięta?) resterylizacja sprzętu jednorazowego oraz duży odsetek angioplastyk balonowych. Muszę zresztą przyznać, że w tych czynnościach chyba zostaliśmy prześcignięci...

Podsumowując - zapraszam do lektury, ciekawego moim zdaniem, artykułu, który z jednej strony pokazuje poziom kardiologii interwencyjnej w Uzbekistanie, a z drugiej uświadamia, jak ta dziedzina rozwinęła się w Polsce. 